\title{
Общественные информационные интернет-кампании в современной России: инструменты и результаты
}

\author{
Ю. А. Палачева, А. В. Соколов \\ Ярославский государственный университет имени П.Г. Демидова \\ palacheva.yulya@mail.ru, alex8119@mail.ru
}

\section{Аннотация}

Успешность общественных кампаний во многом зависит от того, в какой степени их организаторы могуг обеспечить необходимое информационное сопровождение, вовлечение сторонников. В современной ситуации значительную часть подобных действий организаторам удается осуществлять в Интернете. Признанные преимущества глобальной сети предоставляют значимые возможности по указанным направлениям организации общественных кампаний.

В статье представлен анализ общественных информационных кампаний в российском сегменте Интернета в 2019 году. Для обзора были выбраны информационные кампании в поддержку Ивана Голунова и Павла Устинова, общественная информационная кампания о проблеме лесных пожаров на территории Сибири. В обзоре представлены цели общественной информационной кампании, инструменты, а также медийные лица, участвовавшие в данных кампаниях. При подготовке аналитического обзора было проведено анкетирование респондентов, проживающих в Центральном федеральном округе.

Проведённое исследование позволило сделать ряд выводов. Во-первых, большинство респондентов наблюдали в Интернете материалы, связанные с каждой из изучаемых информационных кампаний. Во-вторых, наибольший отклик среди опрошенных вызвала информационная кампания по проблеме лесных пожаров на территории Сибири.

Ключевые слова: Интернет, социальные сети, общественная информационная интернет-кампания, средства массовой информации

Библиографическая ссылка: Палачева Ю.А., Соколов А.В. Общественные информационные интернет-кампании в современной России: инструменты и результаты // Государство и граждане в электронной среде. Выпуск 4 (Труды XXIII Международной объединенной научной конференции «Интернет и современное общество», IMS-2020, Санкт-Петербург, 17 - 20 июня 2020 г. Сборник научных статей). - СПб: Университет ИТМО, 2020. С. 32-45. DOI: 10.17586/2541-979X-4-32-45

\section{1. Введение}

Одной из черт гражданского общества в эпоху развития новых технологий становится организация и проведение различных информационных общественных кампаний в сети Интернет. Информационные общественные кампании дают возможность их организаторам с помощью Интернета и социальных сетей привлечь большое количество сторонников. При правильной подаче информации и поддержке представителей разных медийных групп общественная кампания получает огромное количество сторонников. При этом платформы социальных сетей позволяют распространять информацию о кампании практически без финансовых вложений со стороны организаторов. 
Достаточно получить большой публичный отклик пользователей (лайк, комментарий, репост и т.д.) и запись с информацией о компании попадет в рекомендации потенциальной аудитории.

В российском сегменте Интернета в 2019 году проходили общественные информационные кампании по сохранению сквера в Екатеринбурге [1], по спасению от пожаров лесов в Сибири [2], в поддержку Ивана Голунова [3], Павла Устинова [4], больных муковисцидозом [5], сестер Хачатурян [6], Михаила Галина и кота Виктора [7] и многие другие. Каждая из информационных кампаний помогала привлечь внимание общества и создать общественный резонанс для инфоповода в средствах массовой информации. Некоторые проблемы были полностью решены, например, строительство храма в сквере в Екатеринбурге было приостановлено, Иван Голунов оправдан и т.д. А другие информационные кампании смогли показать необходимость работы с нынешним законодательством (кампания больных муковисцидозом, дело сестер Хачатурян, кампания кота Виктора).

Сегодня технологии по организации и проведению информационных общественных кампаний в сети Интернет становятся доступными каждому пользователю, который имеет доступ к глобальной сети. Некоторые из вышеперечисленных нами информационных кампаний были организованы профессионалами в сфере медиа, а другие - простыми пользователями, которые хотели предать огласке свою проблему.

Отдельно отметим, что в организации информационных кампаний нельзя не учитывать эффективность использования не только Интернета в целом, но и отдельно социальных сетей, а также публикаций у медийных лиц, неформальных лидеров общественного мнения. Пользователи начинают следовать примеру своих кумиров и публичная реакция на контент, его поддержка через лайк, репост, комментарий становится неким объединяющим фактором с медийной личностью.

\section{2. Теоретические аспекты изучаемой проблемы}

При разработке данной проблематики авторами был проведен анализ литературы, в которой упоминалась проблематика организации и проведения «информационных кампаний».

Д.В. Алексеева и Е.Г. Алексеева понимают в своем пособии информационную кампанию как «комплексную систему мер воздействия на определенные группы населения (так называемые целевые группы) с помощью различных средств и каналов массового и индивидуального информирования и обучения с целью побуждения к принятию новых, полезных для них самих и для общества моделей поведения в определенной сфере жизни» [8]. Авторы рассматривают информационную кампанию как часть проведения профилактической работы по профилактике ВИЧ и СПИД. Данное определение используется во многих пособиях для гражданских активистов различных направлений. Например, оно упоминается в «Пособии по привлечению общественности к природоохранным мероприятиям. Как провести информационную кампанию по раздельному сбору отходов?» [9].

И.О. Зайцев в своей работе «Российская информационная кампания в период вооруженного противостояния на востоке Украины в 2014-2015 гг.» рассматривает «информационную кампанию» в контексте действий российских властей, направленных на поддержку позиции России в украинском вопросе [10]. Также автор вводит понятие «военная информационная кампания».

А.Д. Васильев и Ф.Е. Подсохин считают взаимозаменяемыми понятия «информационная кампания» и «информационная война» [11]. Под информационной войной авторы понимают «совокупность массовых коммуникативных практик, целью которых является воздействие (или противодействие) посредством специфического употребления единиц языка на общность людей (географическую, этнографическую, 
конфессиональную, политическую, экономическую и т. д.) при одновременном обеспечении безопасности и защиты актора для достижения информационного превосходства в стратегических целях» [12].

Ю.А. Королев рассматривал понятие «информационная кампания» как «форму организации информационно-коммуникационных взаимодействий, осуществляемых для достижения определенных целей в сфере функционирования власти, принятия решений и реализации государственной политики в пределах установленных временных рамок» [13].

Вышеуказанные определения нельзя применить к процессам, которые происходили в российском сегменте Интернета в 2019 году. На наш взгляд, произошли резонансные явления, когда гражданская активность, направленная на привлечение внимания к проблеме, практически не выходила за пределы интернет-пространства, но при этом достигала значимых результатов. Похожий кейс был рассмотрен В.Н. Степановым в работе «Информационная кампания против объединения Волковского и Александринского театров» [14]. В ней также рассматривались явления, в которые были вовлечены личные и коллективные аккаунты в социальных сетях, СМИ, профессиональные объединения.

Таким образом, считаем необходимым ввести понятие «общественная информационная интернет-кампания», под которой мы будем понимать совокупность действий гражданина или группы лиц в информационном пространстве, направленных на привлечение внимания к общественной проблеме.

\section{3. Характеристика исследования}

Целью настоящего исследования стало выявление и характеристика реакций пользователей Интернета на различные общественные информационные кампании, проходивших в российском интернет-сегменте.

Объектом данного исследования стала реакция молодежи, так как именно эта социальная группа является основной аудиторией интернет-пространства.

В качестве основной гипотезы мы выдвигаем утверждение, что большинство респондентов знают о проведении всех трех информационных кампаний.

Основным методом сбора данных выступил опрос респондентов методом интернетанкетирования с использованием Google-формы. Респонденты привлекались к участию в исследовании через распространение анкеты в различных городских сообществах в социальных сетях. При обработке полученных данных простым случайным способом были исключены «лишние» по структуре выборки анкеты респондентов по полу, возрасту, городу.

Объем выборки составил 425 респондентов из 6 регионов Центрального федерального округа. При выборе регионов для проведения исследования была использована классификация городов: города-миллионеры (более 1 млн жителей), крупнейшие города (от 500 тыс. до 1 млн жителей), крупные города (от 250 тыс. до 500 тыс.). Для исследования были выбраны два региона с городами-миллионерами (город Москва и Воронежская область), два региона с крупнейшими городами (Тульская область и Ярославская область), два региона с крупными городами (Ивановская область, Тверская область).

Опрос проводился среди молодежи в возрасте от 16 до 29 лет. Доля мужчин и женщин рассчитывалась в каждом регионе индивидуально на основе данных Всероссийской переписи населения [15] и представлена в Таблице 1.

Для проведения опроса была составлена анкета, включающая идентичные вопросы для всех трех кампаний, связанные с информированностью о проведении информационных кампаний («Видели ли Вы в социальных сетях посты, истории, связанные с...»), с оценкой реакций респондентов («Реагировали ли Вы каким-либо образом на информацию в социальных сетях, связанную с...»), с информированностью о поддержке кампаний 
медийными лицами («Видели ли Вы посты, истории об ... у медийных лиц, на которых Вы подписаны? (журналисты, блогеры, актеры, политики, артисты и т.д.)»).

Таблица 1. Распределение респондентов в регионах

\begin{tabular}{|c|c|c|c|c|c|c|}
\hline & \multicolumn{4}{|c|}{$\begin{array}{c}\text { Соотношение мужчин и женщин в возрасте от } \\
16 \text { до 29 лет, в \% }\end{array}$} & \multirow{2}{*}{\multicolumn{2}{|c|}{$\begin{array}{c}\text { Соотношение мужчин } \\
\text { и женщин в возрасте } \\
\text { от } 16 \text { до } 29 \text { лет, чел } \\
\text { в настоящем } \\
\text { исследовании }\end{array}$}} \\
\hline & \multicolumn{2}{|c|}{$\begin{array}{c}\text { согласно } \\
\text { Всероссийской } \\
\text { переписи населения }\end{array}$} & \multicolumn{2}{|c|}{$\begin{array}{c}\text { в настоящем } \\
\text { исследовании }\end{array}$} & & \\
\hline & мужчины & женщины & мужчины & женщины & мужчины & женщины \\
\hline $\begin{array}{l}\text { город } \\
\text { Москва }\end{array}$ & 49,1 & 50,9 & 49,3 & 50,7 & 35 & 36 \\
\hline $\begin{array}{l}\text { Воронежская } \\
\text { область }\end{array}$ & 50,5 & 49,5 & 50,7 & 49,3 & 36 & 35 \\
\hline $\begin{array}{l}\text { Ивановская } \\
\text { область }\end{array}$ & 51,6 & 48,4 & 51,5 & 48,5 & 36 & 34 \\
\hline $\begin{array}{l}\text { Тверская } \\
\text { область }\end{array}$ & 51,5 & 48,5 & 52,1 & 47,9 & 37 & 34 \\
\hline $\begin{array}{l}\text { Тульская } \\
\text { область }\end{array}$ & 51,3 & 48,7 & 51,4 & 48,6 & 36 & 34 \\
\hline $\begin{array}{l}\text { Ярославская } \\
\text { область }\end{array}$ & 49,9 & 50,1 & 49,3 & 50,1 & 35 & 37 \\
\hline Всего & & & & & 215 & 210 \\
\hline
\end{tabular}

Для каждой информационной кампании были составлены индивидуальные вопросы для оценки уровня влияния: «Согласны ли Вы с утверждением: «Гражданская активность в социальных сетях повлияла на закрытие дела Ивана Голунова»?», «Согласны ли Вы с утверждением: «Гражданская активность в социальных сетях повлияла на пересмотр дела Павла Устинова»?», «Согласны ли Вы с утверждением: «Гражданская активность в социальных сетях повлияла на решение властей об использовании авиации при тушении лесных пожаров»?».

\section{4. Информационная общественная кампания в поддержку журналиста Ивана Голунова \#ямыиванголунов}

Наиболее крупной общественной информационной кампаний в российском сегменте Интернета стало дело журналиста интернет-ресурса «Mediza.io» Ивана Голунова. 6 июня 2019 года Иван был задержан в центре Москвы и обвинен в торговле наркотическими средствами. Голунов отрицал свою вину, и его коллеги из интернет-ресурса «Mediza.io» начали общественную информационную кампанию, известную под тегом \#ямыиванголунов. 11 июня уголовное дело спецкора «Медузы» Ивана Голунова было прекращено «в связи с недоказанностью вины». В настоящее время идут следственные мероприятия в отношении сотрудников полиции, задержавших Голунова [16].

В проекте «Год в поиске: \#2019СозданЛюдьми» кампании Google Иван Голунов занимает 9 строчку в рейтинге самых быстрорастущих запросов в категории «Люди года» [17]. Также общественная информационная кампания упоминается в различных рейтингах компании «Медиалогия» [18].

Одну из ключевых ролей в организации данной информационной кампании сыграли именно коллеги Ивана из интернет-ресурса «Mediza.io», а также большое влияние оказал его профессиональный статус журналиста-расследователя. Многие СМИ объединились «из журналистской солидарности» в поддержку Ивана Голунова. Это оказало прямое 
влияние на скорость распространения информации об общественной информационной кампании.

С помощью опроса молодежи, проживающей в различных регионах ЦФО, было установлено, что $84,7 \%$ респондентов видели в Интернете, в том числе в социальных сетях, информацию в поддержку журналиста Ивана Голунова. По количеству информированных о деле Голунова лидирует Тульская область (более 97\% опрошенных). Наименьший уровень информированности отмечен в Ивановской области (70\%).

Учитывая современные особенности распространения контента в сети Интернет, прямое влияние на увеличение просмотров оказывает реакция пользователей. При просмотре контента, связанного с общественной кампанией по делу Голунова, 46,1\% респондентов публично отреагировали на контент, поставив лайк $(23,3 \%)$, прокомментировав ситуацию $(7,1 \%)$, сделав репост $(6,8 \%)$. Опубликовали историю или пост на своей личной странице с информацией о кампании $8,9 \%$ респондентов.

Важно отметить, что мужчины и женщины по-разному реагировали на информационную кампанию по делу Голунова. Среди мужчин отреагировавшие составляют $51 \%$, среди женщин - 40\%. Наиболее популярной формой активности среди мужчин стал «лайк» под постом, его оставили $42 \%$ опрошенных, отреагировавших на посты. Равный процент мужчины оставляли комментарии и делали репосты на личные страницы (21\% в каждом случае). Среди женщин самой популярной формой активности также стало оставление лайка (60\%), 16\% опрошенных женщин-респондентов сделали репост, $16 \%$ - опубликовали пост или историю на своей личной странице. Только $6,9 \%$ женщин, проявивших активность под постами, оставляли комментарий. Таким образом, мужчины и женщины с помощью разных инструментов реагировали на информационную кампанию \#ямыиванголунов, проявляя определенные особенности в формах реакции.

В Таблице 2 представлены реакции респондентов в сопряженности с региональным распределением. В графах «лайк», «комментарий», «репост», «пост/история от первого лица» процент рассчитан исходя из доли отреагировавших. В графе «не реагировал» от общего числа опрошенных в регионе.

Таблица 2. Реакция респондентов на информационную общественную кампанию в поддержку Ивана Голунова (\%)

\begin{tabular}{|c|c|c|c|c|c|c|}
\hline & Лайк & Комментарий & Репост & $\begin{array}{c}\text { Пост/история } \\
\text { от первого } \\
\text { лица }\end{array}$ & $\begin{array}{c}\text { Не } \\
\text { реагировал }\end{array}$ & $\begin{array}{c}\text { Публично } \\
\text { отреагиро- } \\
\text { вали }\end{array}$ \\
\hline г. Москва & 47,5 & 20,0 & 17,5 & 15,0 & 43,6 & 56,4 \\
\hline $\begin{array}{l}\text { Воронежская } \\
\text { область }\end{array}$ & 50,0 & 16,7 & 27,8 & 5,5 & 49,2 & 50,8 \\
\hline $\begin{array}{l}\text { Ивановская } \\
\text { область }\end{array}$ & 39,2 & 17,4 & 17,4 & 26,0 & 67,1 & 32,9 \\
\hline $\begin{array}{l}\text { Тверская } \\
\text { область }\end{array}$ & 70,4 & 18,5 & 7,4 & 3,7 & 61,9 & 38,1 \\
\hline $\begin{array}{l}\text { Тульская } \\
\text { область }\end{array}$ & 30,8 & 17,9 & 2,6 & 48,7 & 44,2 & 55,8 \\
\hline $\begin{array}{l}\text { Ярославская } \\
\text { область }\end{array}$ & 71,0 & 0,0 & 16,1 & 12,9 & 56,9 & 43,1 \\
\hline
\end{tabular}

На основе анализа данных, представленных в Таблице 2, делаем следующие выводы:

1) Наибольший процент респондентов, публично отреагировавших на информационную кампанию в поддержу Ивана Голунова, проживает в городе Москва. В Тульской области также высокий процент отреагировавших респондентов;

2) Для большинства регионов наиболее популярной формой реакции становится «лайк» к посту с информационной кампанией. Исключением является Тульская область, 
где самой частой формой активности респондентов стали посты или истории в собственных аккаунтах об информационной кампании.

Одной из характерных черт информационной кампании в поддержку Голунова становится некое сплочение профессионального сообщества, а затем привлечение внимания интернет-пользователей. $\mathrm{B}$ дальнейшем похожий кейс вовлечения пользователей сети с помощью авторитета профессионального сообщества будет использован в кампании в поддержку актера Павла Устинова и хирурга Михаила Кабака. Среди опрошенных нами респондентов $73,4 \%$ видели в сети Интернет посты, истории различных медийных лиц в поддержку Ивана Голунова. В качестве примеров респонденты называли телеведущую Ксению Собчак (https://www.instagram.com/p/ByaL7dFgRoo), телеведущего, актера Ивана Урганта (https://www.instagram.com/p/ByijYN-C_K0), общественного деятеля и видеоблогера Илью Варламова (https://www.instagram.com/p/B0fxvb_A-mR), журналиста и видеоблогера Юрия Дудя (https://www.instagram.com/p/ByaNnzzFFIt), актера Александра Петрова (https://www.instagram.com/p/Byi9W_1AuaE), рок-музыканта Сергея Шнурова (https://www.instagram.com/p/ByhnZv3ILMe), комедийного актера кино и телевидения Семена Слепакова (https://www.instagram.com/p/BygCr0MnavQ), музыканта Василия Вакуленко («Баста») (https://www.instagram.com/p/Byh-jlroZ7m) и других.

Важно отметить, что респонденты признают значимость гражданской активности в социальных сетях, указывают, что она повлияла на закрытие дела Ивана Голунова. С этим утверждением согласилось $82,4 \%$ респондентов. В региональном соотношении эффективность информационной кампании чаще всего отмечали в г. Москва $(88,5 \%)$ и в Тульской области $(85,7 \%)$, меньше всего - в Ивановской области $(72,8 \%)$.

Если данный вопрос рассматривать в сопряженности с гендером респондентов, то с утверждением согласны $86 \%$ мужчин и 78\% женщин. При измерении сопряженности оценки респондентами собственного уровня гражданской активности и влияния информационной кампании $86 \%$ респондентов, которые считают себя человеком с активной гражданской позицией, согласны с вышеуказанным утверждением о влиянии информационной кампании на закрытие уголовного дела в отношении Ивана Голунова. Среди респондентов, которые не считают себя людьми с активной гражданской позицией, согласны с утверждением $79 \%$.

Таким образом, большинство опрошенных респондентов наблюдали в сети Интернет информацию, посвященную поддержке Ивана Голунова, а также считают, что проведение общественной информационной кампании оказало влияние на закрытие дела Ивана Голунова.

\section{5. Информационная общественная кампания в поддержку актера Павла Устинова \#ямыпавелустинов}

Павел Устинов - российский актер театра и кино. Широкую известность Устинов получил после митингов 3 августа, стал одним из фигурантов «московского дела». Был приговорен к 3,5 годам за то, что он вывихнул плечо сотруднику Росгвардии Александру Лягину. После масштабной общественной кампании под хештегом \#ямыпавелустинов приговор был обжалован и изменен на один год условно [19]. Во многом в организации и проведении информационной кампании в поддержку Павла Устинова были использованы приемы из кейса о деле Ивана Голунова. Это отражается не только в обращениях различных мейдиных лиц в своих аккаунтах в социальных сетях, но и в использовании похожего тега \#ямыпавелустинов, а также в графическом оформлении кампании. В проекте «Год в поиске: \#2019СозданЛюдьми» компании Google Павел Устинов занимает 10 строчку в рейтинге самых быстрорастущих запросов в категории «Люди года» [20].

Среди опрошенных респондентов только 67,3\% видели в сети Интернет информацию, посвященную кампании \#ямыпавелустинов. По уровню осведомленности жителей первое 
место занимает Тульская область (77\% респондентов), второе место - город Москва (76\% респондентов). Наименьшая информированность среди опрошенных наблюдается в Ивановской области (55\%). Процент осведомленности об информационной кампании при гендерном распределении составляет среди мужчин 69\% и среди женщин $64 \%$.

Количество респондентов, которые как-либо отреагировали на контент, посвященный Павлу Устинову, составляет всего 26\%. Наиболее частой реакцией становился поставленный лайк $(17,8 \%)$, оставили комментарий $(3 \%)$, сделали репост $(1,6 \%)$. Посвятили пост или историю на своей личной странице $3 \%$ опрошенных.

Отметим, что мужчины и женщины вновь по-разному реагировали на информационную кампанию. Из доли публично отреагировавших на кампанию мужчин $58 \%$ поставили «лайк», 23\% - прокомментировали запись, $13 \%$ - опубликовали пост или историю на своей личной странице. Большинство женщин в информационной кампании в поддержку Павла Устинова ограничились лайком (данную форму указали 78\% опрошенных).

В Таблице 3 представлены реакции респондентов на информационную общественную кампанию в поддержку Павла Устинова в сопряженности с региональным распределением. В графах «лайк», «комментарий», «репост», «пост/история от первого лица» процент рассчитан исходя из доли отреагировавших. В графе «не реагировал»- от общего числа опрошенных в этом регионе.

Таблица 3. Реакция респондентов на информационную общественную кампанию в поддержку Павла Устинова (\%)

\begin{tabular}{|c|c|c|c|c|c|c|}
\hline & Лайк & $\begin{array}{c}\text { Коммент } \\
\text { арий }\end{array}$ & Репоост & $\begin{array}{c}\text { Пост/история } \\
\text { от первого } \\
\text { лица }\end{array}$ & $\begin{array}{c}\text { Не } \\
\text { реагировал }\end{array}$ & $\begin{array}{c}\text { Публично } \\
\text { отреагировали }\end{array}$ \\
\hline Москва & 73,9 & 13,0 & 8,7 & 4,4 & 67,6 & 32,4 \\
\hline $\begin{array}{l}\text { Воронежская } \\
\text { область }\end{array}$ & 76,0 & 16,0 & 4,0 & 4,0 & 64,8 & 35,2 \\
\hline $\begin{array}{l}\text { Ивановская } \\
\text { область }\end{array}$ & 55,6 & 11,1 & 11,1 & 22,2 & 87,1 & 12,9 \\
\hline $\begin{array}{l}\text { Тверская } \\
\text { область }\end{array}$ & 80,0 & 20,0 & 0,0 & 0,0 & 85,9 & 14,1 \\
\hline $\begin{array}{l}\text { Тульская } \\
\text { область }\end{array}$ & 43,5 & 21,7 & 4,3 & 30,5 & 67,1 & 32,9 \\
\hline $\begin{array}{l}\text { Ярославская } \\
\text { область }\end{array}$ & 77,5 & 4,5 & $9,0 \%$ & 9,0 & 69,4 & 30,6 \\
\hline
\end{tabular}

На основе анализа данных, представленных в Таблице 3, делаем следующие выводы:

1) Наибольший процент респондентов, публично отреагировавший на информационную кампанию в поддержу Павла Устинова, проживает в Воронежской области. В городе Москва также высокий процент отреагировавших респондентов;

2) Для большинства регионов наиболее популярной формой реакции становится «лайк» к посту с информационной кампанией.

Можно предположить, что влияние на более низкий по сравнению с делом Ивана Голунова уровень вовлеченности в общественную информационную кампанию связан со следующими причинами:

1) Кейс информационной кампании по поддержке Павла Устинова сильно дублировался с раннее проведенной информационной кампанией в поддержку Ивана Голунова. Это могло оказать влияние на респондентов;

2) Павел Устинов чаще всего играл в кино роли второго плана и не был особо известен респондентам. Предположим, что Иван Голунов также не был известен большинству респондентов [21], но в этом кейсе огромное влияние оказало распространение текстов его расследований в средствах массовой информации; 
3) По данным ОВД-Инфо, 26 человек стали фигурантами «московского дела» [22]. Таким образом, Павел Устинов был не единственным задержанным, в отношении кого проводились следственные мероприятия. Это также могло оказать влияние на интерес респондентов к общественной информационной кампании.

Среди опрошенных респондентов 56,2\% наблюдали в Интернете посты, истории медийных лиц в поддержку Павла Устинова. Это на 17,2\% ниже, чем в кампании \#ямыиванголунов. Респонденты отмечали, что в поддержку Павла Устинова в своих аккаунтах в социальных сетях высказались Максим Галкин (https://www.instagram.com/tv/B2gGta6HZk0), журналист Юрий Дудь (https://www.instagram.com/p/B2goKiFlisS), (https://www.instagram.com/p/B2gYsPfDEXb), (https://www.instagram.com/p/B2g41pJDAUh) (https://www.instagram.com/p/B2fNFBcIrMP), актриса

и

телеведущий
Александра

Тимур

Сергей Дмитрий
Бортич

Родригез

Лазарев

Нагиев (https://www.instagram.com/p/B2hGqAmD5xD).

Важно отметить, что респонденты признают значимость гражданской активности в социальных сетях, указывают, что она повлияла на пересмотр дела Павла Устинова. С этим утверждением согласилось $62,4 \%$ респондентов. Здесь оказать влияние на мнение респондентов могло сохранение обвинительного приговора (Павел Устинов приговорен к году условно).

В дальнейшем данная информационная кампания перешла в кампании под тегами \#ямывсястрана, \#свободуполитзаключенным, \#сядьзатекст. Они направлены в поддержку фигурантов «московского дела», которым было предъявлено обвинение. Другим известным фигурантом «московского дела» является студент Егор Жуков [23].

\section{6. Информационная общественная кампания, посвященная пожарам в Сибири}

По уровню вовлеченности и масштабу последствий наиболее крупной в рунете стала общественная информационная кампания, посвященная пожарам в Сибири. В июле 2019 года на территории Сибири начались лесные пожары. Региональные органы власти отказывались их тушить, так как они входят в «зону контроля» (ущерб пожара оценивается ниже, чем расходы на его тушение). Наибольший общественный резонанс кампания получила после выступления губернатора Красноярского края Александра Усса, в котором он заявил, что «это обычное природное явление, бороться с которым бессмысленно, а может, даже где-то и вредно». Фраза «экономически невыгодно» получила большую популярность в сети.

Среди исследуемых нами информационных общественных кампаний, интернетактивность, посвященная проблеме лесных пожаров на территории Сибири, оказалась наиболее масштабной. Посты, истории, посвященные ей, видели в Сети 97,4\% респондентов. Столь высокий процент респондентов можно обосновать тем, что данная проблема в той или иной мере затрагивает всех респондентов. Горящий лес, который в российском менталитете считается одним из богатств нашей страны, стал для многих более личной проблемой, чем дело Ивана Голунова и Павла Устинова. Можно предположить, что на вовлечение в информационные кампании Голунова или Устинова в той или иной мере могуг оказывать влияние политические взгляды (Устинов был задержан во время одного из «московских протестов») или отношение к журналистамрасследователям и изданиям как «Mediza.io».

Данная информационная кампания получила наибольший публичный отклик среди респондентов. Не отреагировали на информационную кампанию всего $31,3 \%$. Поставили лайк $-27,1 \%$, оставили комментарий $-8,7 \%$, сделали репост $-14,1 \%$, посвятили пост или историю на своем личном аккаунте - 18,8\%. Распределение реакций опрошенных пользователей в регионах представлено в Таблице 4. В графах «лайк», «комментарий», 
«репост», «пост/история от первого лица» процент рассчитан исходя из доли отреагировавших. В графе «не реагировал» - от общего числа опрошенных в этом регионе.

Таблица 4. Реакция респондентов на информационную общественную кампанию в Сибири (\%)

\begin{tabular}{|c|c|c|c|c|c|c|}
\hline & Лайк & $\begin{array}{c}\text { Коммента } \\
\text { рий }\end{array}$ & Репост & $\begin{array}{c}\text { Пост/история } \\
\text { от первого } \\
\text { лица }\end{array}$ & $\begin{array}{c}\text { Не } \\
\text { реагировал }\end{array}$ & $\begin{array}{c}\text { Публично } \\
\text { отреагирова } \\
\text { ли }\end{array}$ \\
\hline г.Москва & 51,0 & 10,6 & 19,4 & 19,0 & 33,8 & 66,2 \\
\hline $\begin{array}{l}\text { Воронежская } \\
\text { область }\end{array}$ & 65,9 & 15,9 & 11,4 & 6,8 & 38,8 & 61,2 \\
\hline $\begin{array}{l}\text { Ивановская } \\
\text { область }\end{array}$ & 18,2 & 12,7 & 23,6 & 45,5 & 21,4 & 78,6 \\
\hline $\begin{array}{l}\text { Тверская } \\
\text { область }\end{array}$ & 32,6 & 13,0 & 21,7 & 32,7 & 34,3 & 65,7 \\
\hline $\begin{array}{l}\text { Тульская } \\
\text { область }\end{array}$ & 36,0 & 12,0 & 22,0 & 30,0 & 29,6 & 70,4 \\
\hline $\begin{array}{l}\text { Ярославская } \\
\text { область }\end{array}$ & 38,0 & 12,0 & 24,0 & 26,0 & 29,6 & 70,4 \\
\hline
\end{tabular}

Отметим, что, исходя из вышепредставленной таблицы, наибольший процент публично прореагировавших на информационную кампанию находится в Ивановской области, Тульской и Ярославской области. Процент отреагировавших в городах-миллионниках ниже, чем в кампаниях Голунова и Устинова. Можно предположить, что более высокая активность регионов в данной кампании связана с тем, что проблема горящих лесов для респондентов является более близкой, чем задержание журналиста в Москве или арест актера во время проведения несанкционированных митингов в Москве.

Однако 89,6\% респондентов наблюдали в социальных сетях у своих кумиров посты и истории, посвященные пожарам в Сибири. Респонденты отмечали, что призывы подписать петицию видели в социальных сетях у телеведущего Максима Галкина (https://www.instagram.com/tv/B0irpM9nZ8D), видеоблогера Ильи Варламова (https://www.instagram.com/p/Byaw4HRATzr), рок-музыканта Сергея Шнурова (https://www.instagram.com/p/B0askKJh908), комедийного актера кино и телевидения Семена Слепакова (https://www.instagram.com/p/B0jtzB-HPUD), музыканта Василия Вакуленко («Баста») (https://www.instagram.com/tv/B0YzsXyFevY), певицы Полины Гагариной (https://www.instagram.com/p/B0ffVwRo7md), музыканта Сергея Лазарева (https://www.instagram.com/p/B0fq6QPIhHj/) и других.

Отдельно хотим отметить, что медийные лица не только призывали подписать петицию и рассказать о проблеме на своих личных страницах, но и посвящали ей свое творчество. Так, например, певица «Монеточка» выпустила песню «Гори» и написала в своем аккаунте в сети «Instagram» (https://www.instagram.com/p/B083gAGh_i8): «Bce деньги, собранные с прослушивания этого трека на стриминговых сервисах отправятся на приобретение ранцевых огнетушителей, воздуходувок-опрыскивателей, навигаторов и на покрытие других важных расходов в рамках программы Гринпис по борьбе с пожарами на природных территориях, вплоть до инициативы по внесению изменений в школьные учебники, в некоторых из которых были найдены ошибочные советы по противодействию огню и предотвращению возгораний». При этом только 57,9\% опрошенных респондентов считают, что гражданская активность в социальных сетях повлияла на решение властей об использовании авиации при тушении лесных пожаров.

Можно предположить, что столь небольшой процент (по сравнению с раннее описанными информационными кампаниями) связан с тем, что авиация была привлечена на позднем этапе, когда сгорел лес на огромных территориях. В 
некоторых средствах массовой информации отмечалось, что авиация была задействована, чтобы успокоить население [24]. Эксперты оценивали эту работу как малоэффективную.

\section{7. Выводы}

В 2019 году в российском интернет-пространстве было проведено несколько общественных информационных кампаний. Они касались как судеб конкретных людей (Павел Устинов, Иван Голунов), так и всех жителей страны (пожары в Сибири).

Информационная общественная кампания в поддержку журналиста Ивана Голунова стала одной из самых тиражируемых, согласно исследованиям компании Google и «Медиалогии». Особенностью данной кампании стал наибольший процент респондентов, которые были согласны с угверждением «Гражданская активность в социальных сетях повлияла на закрытие дела Ивана Голунова», а значит, уверены в эффективности ее проведения.

Можно предположить, что информационная кампания в поддержку Ивана Голунова, которая была подготовлена и проведена профессионалами в сфере медиа, стала неким кейсом использования сети Интернет для решения проблем конкретных людей. Тег \#ямы стал не только частью информационной кампании Ивана Голунова, но и использовался в кампаниях в поддержку сестер Хачатурян (\#ямысестрыхачатурян), в кампании по поддержке фигурантов «московского дела» (\#ямывсястрана), в освещении конфликта компании «Аэрофлот» и Михаила Галина, хозяина кота Виктора (\#ямытолстыйкот) и других.

Кампания в поддержку актера Павла Устинова стала наименее известной среди респондентов настоящего исследования. Информацию о ней в социальных сетях видели всего $67,3 \%$ респондентов. Мы предположили, что это связано с частичным дублированием кейса кампании Ивана Голунова и наличием других задержанных в рамках «московского дела». С утверждением об эффективности настоящей информационной кампании согласились всего 62,4\% респондентов. Возможно, данный процент связан тем, что Павел Устинов был приговорен к одному году условно. Отдельно отметим, что кампания в поддержку Устинова переросла в кампании \#ямывсястрана, \#сядьзатекст, \#свободуполитзаключенным.

Информационная общественная кампания по спасению лесов Сибири от лесных пожаров была известна 97,4\% респондентов. Предположительно, такой высокий процент информированности связан доступностью и понятностью для респондентов из регионов проблемы горящих лесов. С другой стороны, данная информационная общественная кампания стала самой неэффективной из исследуемых, по мнению респондентов. С утверждением «Гражданская активность в социальных сетях повлияла на решение властей об использовании авиации при тушении лесных пожаров» были согласны всего 57,9\%. Предположим, что это связано с тем, что большая территория лесов Сибири на момент подключения авиации к тушению уже сгорела.

Подводя итоги, отметим, что 2019 год стал для российского сегмента Интернета резонансным. Появились кейсы, на основании которых возможно проведение общественной информационной кампании исключительно в сети Интернет. При этом уже реализованные кампании демонстрируют нам, что они могуг быть узнаваемыми, успешными в достижении поставленных задач.

Статья подготовлена в рамках исследования, финансируемого за счет гранта Президента Российской Федерации для государственной поддержки молодых российских ученых МД-855.2020.6 «Мобилизация и демобилизация в современных практиках протестной активности». 


\section{Литература}

[1] Храм или сквер: история конфликта в Екатеринбурге. URL: https://www.ntv.ru/novosti/2190502/ (дата обращения 02.02.2020).

[2] Море огня. Как горит сибирский лес - и почему никто не может остановить этот пожар. URL: https://meduza.io/feature/2019/08/06/more-ognya (дата обращения 02.02.2020).

[3] Уголовное дело против корреспондента «Медузы» Ивана Голунова. Главное. URL: https://meduza.io/feature/2019/06/07/ugolovnoe-delo-protiv-korrespondenta-meduzy-ivanagolunova-glavnoe (дата обращения 02.02.2020).

[4] Дело Павла Устинова. URL: https://www.interfax.ru/chronicle/delo-pavla-ustinova.html (дата обращения 02.02.2020 г.).

[5] Я не знаю, чем лечить ребенка. В России заканчиваются качественные лекарства для пациентов с муковисцидозом. Одна из причин - импортозамещение. URL: https:// meduza.io/feature/2019/11/28/ya-ne-znayu-chem-lechit-rebenka (дата обращения 02.02.2020).

[6] Буду бить за все, убивать буду: обнародована переписка Михаила Хачатуряна с дочкой. URL: https://www.yar.kp.ru/daily/27027/4090715/ (дата обращения 02.02.2020).

[7] Пассажир, которого не пустили в самолет из-за толстого кота: «Мне пришлось пойти на хитрость, не бросать же друга». URL: https:/www.nnov.kp.ru/daily/27052/4118563/ (дата обращения 02.02.2020).

[8] Алексеева Д.В., Алексеева Е. Г. «Информационные кампании по ВИЧ/ СПИДу» (пособие для организаторов) URL: https://child-protection.ru/category/books/ page/7 (дата обращения 02.02.2020).

[9] Деревяго Т., Лабода С. Как провести информационную кампанию по раздельному сбору отходов? Пособие по привлечению общественности к природоохранным мероприятиям // Мн., 2006. 48 с.

[10] Зайцев И.О. Российская информационная кампания в период вооруженного противостояния на востоке Украины в 2014-2015 гг // РСМ. 2018. №3 (100). С. 213-222. URL: https://elibrary.ru/item.asp?id=36318819 (дата обращения: 29.05.2020).

[11] Васильев А.Д., Подсохин Ф.Е. От прецедента к стереотипу: три этапа информационной кампании // Политическая лингвистика. 2016. № 6. C. 32-37. URL: http://elar.uspu.ru/bitstream/uspu/5102/1/plin-2016-06-03.pdf (дата обращения: 29.03.2020).

[12] Васильев А. Д., Подсохин Ф. Е. Информационная война: лингвистический аспект // Политическая лингвистика. 2016. Вып. 2 (56). С. 10-16.

[13]Королев Ю.А. Информационные политические кампании в регионе: манипулирование повесткой дня (на примере Саратовской области) // Вестник ПАГС. 2009. №2. URL: https://elibrary.ru/item.asp?id=18054670 (дата обращения: 29.05.2020).

[14] Степанов В.Н. Информационная кампания против объединения Волковского и Александринского театров // Сборник научных трудов в честь М.Б. Ротановой. Под редакцией А.Д. Кривоносова. 2020. С. 73-79.

[15]Всероссийская перепись населения $2010 \quad$ г. URL: https://www.gks.ru/free_doc/new_site/perepis2010/croc/perepis_itogi1612.htm (дата обращения 02.02.2020 г.).

[16]По делу Ивана Голунова задержаны бывшие сотрудники московской полиции. Их обвинят в фальсификации доказательств и хранении наркотиков. URL: https://meduza.io/feature/2020/01/29/po-delu-ivana-golunova-zaderzhany-byvshiesotrudniki-moskovskoy-politsii-ih-mogut-obvinit-v-falsifikatsii-dokazatelstv-i-hraneniinarkotikov (дата обращения 02.02.2020).

[17]Официальный блог Google Россия: Год в поиске: \#2019СозданЛюдьми. URL: https://russia.googleblog.com/2019/12/2019.html (дата обращения 02.02.2020). 
[18]Компания «Медиалогия» подготовила рейтинг самых цитируемых СМИ за июнь 2019 года. URL: https://www.mlg.ru/ratings/media/federal/6787/(дата обращения 02.02.2020).

[19] Абсурд, полнейший абсурд Актер Павел Устинов получил три с половиной года по «московскому делу». Репортаж Кристины Сафоновой. URL: https://meduza.io/feature/2019/09/16/eto-uzhe-ne-kafka-eto-bosh (дата обращения 02.02.2020).

[20]Официальный блог Google Россия: Год в поиске: \#2019СозданЛюдьми. URL: https://russia.googleblog.com/2019/12/2019.html (дата обращения 02.02.2020).

[21]Павел Устинов - фильмы - КиноПоиск. URL: https://www.kinopoisk.ru/name/5786560/ (дата обращения 02.02.2020).

[22]Московское дело: кто эти люди и за что их судят. Гид ОВД-Инфо. URL: https:/ovdinfo.org/articles/2019/10/31/moskovskoe-delo-kto-eti-lyudi-i-za-chto-ih-sudyatgid-ovd-info (дата обращения 02.02.2020).

[23] Кто такой Егор Жуков и почему все о нём говорят. Для тех, кто не следит за новостями. URL: https://mel.fm/povestka_dnya/3680759-egor_zhukov (дата обращения 02.02.2020).

[24]Вы просто отказываетесь слышать правду про пожары в Сибири. URL: https://www.ural.kp.ru/daily/27010/4072087/ (дата обращения 02.02.2020).

\title{
Public Information Campaigns on the Internet in the Modern Russian: Instruments and Results
}

\author{
Yu. A. Palacheva, A. V. Sokolov
}

\section{P.G. Demidov Yaroslavl State University}

The success of the public campaigns mostly depends on the ability of their organizers to provide an adequate informational support, engagement of the followers. Today the organizers can implement the substantial part of such actions via the Internet. The recognized benefits of the global Web offer considerable opportunities within the indicated ways of organizing the public campaigns.

The article represents the analysis of the public informational campaigns in the Russian segment of the Internet in 2019. The review includes the informational campaigns in support of Ivan Golunov and Pavel Ustinov, the informational campaign on the problem of forest fires in Siberia. The review also reflects the purposes of the public informational campaigns, the instruments as well as the public figures, who participated in these campaigns. During the preparation of this analytical review, the respondents residing in the Central federal region were surveyed.

The conducted research allowed to draw several conclusions. First of all, the majority of the respondents saw the information on the Internet related to each informational campaign in question. Secondly, the informational campaign on the problem of forest fires in Siberia caused the strongest response among the respondents.

Keywords: social information campaigns, Internet, mass media, social networks

Reference for citation: Palacheva Yu.A., Sokolov A.V. Public Information Campaigns on the Internet in the Modern Russian: Instruments and Results // The State and Citizens in the Electronic Environment. Vol. 4 (Proceedings of the XXIII International Joint Scientific Conference «Internet and Modern Society», IMS-2020, St. Petersburg, June 17-20, 2020). St. Petersburg: ITMO University, 2020. P. 32-45. DOI: 10.17586/2541-979X-4-32-45 


\section{Reference}

[1] Hram ili skver: istoriya konflikta v Ekaterinburge. URL: https://www.ntv.ru/novosti/2190502/ (data obrashcheniya 02.02.2020). (in Russian).

[2] More ognya. Kak gorit sibirskij les - i pochemu nikto ne mozhet ostanovit' etot pozhar. URL: https://meduza.io/feature/2019/08/06/more-ognya (data obrashcheniya 02.02.2020). (in Russian).

[3] Ugolovnoe delo protiv korrespondenta «Meduzy» Ivana Golunova. Glavnoe. URL: https://meduza.io/feature/2019/06/07/ugolovnoe-delo-protiv-korrespondenta-meduzyivana-golunova-glavnoe (data obrashcheniya 02.02.2020). (in Russian).

[4] Delo Pavla Ustinova. URL: https://www.interfax.ru/chronicle/delo-pavla-ustinova.html (data obrashcheniya 02.02.2020 g.). (in Russian).

[5] YA ne znayu, chem lechit' rebenka. V Rossii zakanchivayutsya kachestvennye lekarstva dlya pacientov s mukoviscidozom. Odna iz prichin — importozameshchenie. URL: https://meduza.io/feature/2019/11/28/ya-ne-znayu-chem-lechit-rebenka (data obrashcheniya 02.02.2020). (in Russian).

[6] Budu bit' za vse, ubivat' budu: obnarodovana perepiska Mihaila Hachaturyana s dochkoj. URL: https://www.yar.kp.ru/daily/27027/4090715/ (data obrashcheniya 02.02.2020). (in Russian).

[7] Passazhir, kotorogo ne pustili v samolet iz-za tolstogo kota: «Mne prishlos' pojti na hitrost', ne brosat' zhe druga». URL: https://www.nnov.kp.ru/daily/27052/4118563/ (data obrashcheniya 02.02.2020). (in Russian).

[8] Alekseeva D. V., Alekseeva E. G. «Informacionnye kampanii po VICH/SPIDu» (posobie dlya organizatorov) URL: https://child-protection.ru/category/books/page/7. (in Russian).

[9] Derevyago T., Laboda S. Kak provesti informacionnuyu kampaniyu po razdel'nomu sboru othodov? Posobie po privlecheniyu obshchestvennosti $\mathrm{k}$ prirodoohrannym meropriyatiyam // Mn., 2006. 48 s. (in Russian).

[10]Zajcev I.O. Rossijskaya informacionnaya kampaniya $\mathrm{v}$ period vooruzhennogo protivostoyaniya na vostoke Ukrainy v 2014-2015 gg // RSM. 2018. №3 (100). S. 213 222. URL: https://elibrary.ru/item.asp?id=36318819 (data obrashcheniya: 29.05.2020). (in Russian).

[11]Vasil'ev A.D., Podsohin F.E. Ot precedenta k stereotipu: tri etapa informacionnoj kampanii // Politicheskaya lingvistika. 2016. № 6. S. 32-37. URL: http://elar.uspu.ru/bitstream/uspu/5102/1/plin-2016-06-03.pdf (data obrashcheniya: 29.03.2020). (in Russian).

[12]Vasil'ev A. D., Podsohin F. E. Informacionnaya vojna: lingvisticheskij aspekt // Politicheskaya lingvistika. 2016. Vyp. 2 (56). S. 10-16. (in Russian).

[13] Korolev YU.A. Informacionnye politicheskie kampanii v regione: manipulirovanie povestkoj dnya (na primere Saratovskoj oblasti) // Vestnik PAGS. 2009. №2. URL: https://elibrary.ru/item.asp?id=18054670 (data obrashcheniya: 29.05.2020). (in Russian).

[14] Stepanov V.N. Informacionnaya kampaniya protiv ob"edineniya Volkovskogo i Aleksandrinskogo teatrov // Sbornik nauchnyh trudov v chest' M.B. Rotanovoj. Pod redakciej A.D. Krivonosova. 2020. S. 73-79. (in Russian).

[15]Vserossijskaya perepis' naseleniya 2010 g. URL: https://www.gks.ru/free_doc/new_site/perepis2010/croc/perepis_itogi1612.htm (data obrashcheniya 02.02.2020) (in Russian).

[16]Po delu Ivana Golunova zaderzhany byvshie sotrudniki moskovskoj policii. Ih obvinyat $v$ fal'sifikacii dokazatel'sty i hranenii narkotikov. URL: https://meduza.io/feature/2020/01/29/po-delu-ivana-golunova-zaderzhany-byvshie- 
sotrudniki-moskovskoy-politsii-ih-mogut-obvinit-v-falsifikatsii-dokazatelstv-i-hraneniinarkotikov (data obrashcheniya 02.02.2020).

[17] Oficial'nyj blog Google Rossiya: God v poiske: \#2019SozdanLyud'mi. URL: https://russia.googleblog.com/2019/12/2019.html (data obrashcheniya 02.02.2020). (in Russian).

[18]Kompaniya «Medialogiya» podgotovila rejting samyh citiruemyh SMI za iyun' 2019 goda. URL: https://www.mlg.ru/ratings/media/federal/6787/(data obrashcheniya 02.02.2020). (in Russian).

[19]Absurd, polnejshij absurd Akter Pavel Ustinov poluchil tri s polovinoj goda po «moskovskomu delu». Reportazh Kristiny Safonovoj. URL: https://meduza.io/feature/2019/09/16/eto-uzhe-ne-kafka-eto-bosh (data obrashcheniya 02.02.2020). (in Russian).

[20]Oficial'nyj blog Google Rossiya: God v poiske: \#2019SozdanLyud'mi. URL: https://russia.googleblog.com/2019/12/2019.html (data obrashcheniya 02.02.2020). (in Russian).

[21]Pavel Ustinov - fil'my - KinoPoisk. URL: https://www.kinopoisk.ru/name/5786560/ (data obrashcheniya 02.02.2020). (in Russian).

[22]Moskovskoe delo: kto eti lyudi i za chto ih sudyat. Gid OVD-Info. URL: https:/ovdinfo.org/articles/2019/10/31/moskovskoe-delo-kto-eti-lyudi-i-za-chto-ihsudyat-gid-ovd-info (data obrashcheniya 02.02.2020). (in Russian).

[23] Kto takoj Egor ZHukov i pochemu vse o nyom govoryat. Dlya tekh, kto ne sledit za novostyami. URL: https://mel.fm/povestka_dnya/3680759-egor_zhukov (data obrashcheniya 02.02.2020). (in Russian).

[24]Vy prosto otkazyvaetes' slyshat' pravdu pro pozhary $\mathrm{V}$ Sibiri. URL: https://www.ural.kp.ru/daily/27010/4072087/ (data obrashcheniya 02.02.2020) (in Russian). 